\title{
Microbial dynamics associated with leaves decomposing in the mainstem and floodplain pond of a large river
}

\author{
Virginie Baldy ${ }^{1, *}$, Eric Chauvet ${ }^{1}$, Jean-Yves Charcosset ${ }^{1}$, Mark O. Gessner ${ }^{2}$ \\ ${ }^{1}$ Centre d'Ecologie des Systèmes Aquatiques Continentaux, CNRS-UPS, 29 rue Jeanne Marvig, \\ 31055 Toulouse Cedex, France \\ ${ }^{2}$ Department of Limnology, EAWAG, Limnological Research Center, 6047 Kastanienbaum, Switzerland
}

\begin{abstract}
Aquatic habitats of forested floodplain systems receive large inputs of allochthonous plant litter. We examined the decomposition of, and microbial productivity associated with, leaves of a common floodplain tree, Populus gr. nigra, in the mainstem and floodplain pond of a seventh order river in 2 consecutive years. Litter bags were submerged at both sites, retrieved periodically, and analyzed for litter mass loss, bacterial and fungal biomass, growth rate and production, and sporulation rates of aquatic hyphomycetes. Litter decomposition rates were similar in both sites and years (leaf breakdown coefficients $k$ of 0.0070 to $0.0085 \mathrm{~d}^{-1}$ ), although microbial dynamics partly differed between sites. Species diversity of aquatic hyphomycetes was lower on leaves submerged in the pond (16 species) than in the river ( 21 species). Mycelial biomass was also significantly lower in the pond, with values $<20 \mathrm{mgC} \mathrm{g}^{-1}$ of detrital C, whereas peaks of 50 and $80 \mathrm{mg} \mathrm{C} \mathrm{g}^{-1}$ were reached in leaves in the mainstem. These differences contrast with the comparable fungal productivity at both sites (peak rates of $1.4 \mathrm{mg}$ of mycelial C per $\mathrm{g}$ of detrital C per day in both years). This suggests that fungi were equally productive in both habitats but experienced greater losses in the pond. Bacterial numbers and biomass also showed the same basic pattern at both sites, although somewhat higher levels were reached in the pond (maximum of about $10^{10}$ cells and $0.5 \mathrm{mg} \mathrm{g}^{-1}$ of detrital C). Bacterialspecific production rates fluctuated between 0.06 and $1.5 \mathrm{~d}^{-1}$ with lower values occurring in the floodplain pond. Although bacteria on leaves were clearly outweighed by fungi in terms of biomass, they accounted for a sizeable fraction of the total biomass (up to $11 \%$ ), and up to $32 \%$ of the total microbial production. Our comparison of bacterial and fungal productivity thus points to a critical role of fungi in litter decomposition in aquatic habitats of river floodplain systems, while suggesting that bacteria must not be overlooked as important agents of litter decompositon in riverine environments.
\end{abstract}

KEY WORDS: Fungi $\cdot$ Bacteria $\cdot$ Leaf litter $\cdot$ River $\cdot$ Floodplain $\cdot$ Decomposition $\cdot$ Microbial production

\section{INTRODUCTION}

Floodplain river systems are composed of a mosaic of aquatic habitats, whose number and spatial extent vary in response to the frequency, duration and magni-

${ }^{*}$ Present address: Laboratoire de Biosystématique et Ecologie Méditerranéenne, Institut Méditerranéen d'Ecologie et de Paléoécologie, Faculté des Sciences et Techniques de StJérôme, Case 421 bis, Avenue Escadrille Normandie Niemen, 13397 Marseille Cedex 20, France.

E-mail: virginie.baldy@univ.u-3mrs.fr tude of flooding, associated geomorphological reconfigurations of the floodplain, and the kind and degree of subsurface hydrological connectivity (e.g. Ward et al. 2002). The physical, chemical and biological attributes of the individual habitats also vary in both space and time in relation to these factors. Major types of lotic habitats in river floodplains include the mainstem with several distinct 'subhabitats', secondary channels, emergent springbrooks, and tributary streams. In addition, various kinds of standing water bodies are typically present. They also differ in size, temporal 
persistence, water quality (e.g. temperature, turbidity, chemical composition), sediment grain size distribution and organic matter content, and hence in biological characteristics (Tockner et al. 1999).

A salient feature of river floodplain forests is their high primary productivity (Naiman \& Decamps 1997). It results in large inputs of litter to both the forest floor and a range of lentic and lotic water bodies. A large portion of these inputs occurs in the form of autumnshed leaves from the riparian vegetation (Chauvet \& Jean-Louis 1988, Cuffney 1988), suggesting that leaf decomposition constitutes a vital process in floodplain river systems (Chauvet 1988, Chergui \& Pattee 1990, McArthur et al. 1994, Thorp \& Delong 1994). Prior to the fundamental alterations of river morphology and riparian vegetation by man, the importance of litter inputs and decomposition to overall system functioning must have been even greater (Naiman \& Decamps 1997).

Litter decomposition has been studied extensively in both forests and streams, particularly small ones, but has received scant attention in floodplain systems (Chauvet 1988, Mayack et al. 1989, McArthur et al. 1994, Chergui \& Pattee 1990). In streams, litter decomposition involves fungi and bacteria in addition to shear stress and detritivorous invertebrates, with current evidence suggesting that a fungal group known as aquatic hyphomycetes plays a predominant role in the microbial degradation of leaves (Bärlocher 1992, Maltby 1992, Gessner et al. 1997, Suberkropp 1998a). Although aquatic hyphomycetes are primarily known from headwater streams, they also occur abundantly on leaf litter in the mainstem of large rivers (Chergui \& Pattee 1988, Baldy et al. 1995). Their dominance in lotic environments contrasts with a notable scarcity in lentic habitats, eutrophic ones in particular, where they may be replaced by other fungi (Webster \& Descals 1981, Voronin 1992, M. O. Gessner unpubl. data). Chergui \& Pattee (1988) even proposed that the virtual absence of aquatic hyphomycetes from an oxbow lake on the Rhone River floodplain may have accounted for the reduced decomposition rates compared to both the main river channel and a hydrologically connected backwater.

Bacteria in large river systems have been subject to a greater number of studies than fungi (e.g. Baldy et al. 1995, Sinsabaugh \& Findlay 1995), including some on lentic floodplain habitats (Kirschner \& Velimirov 1999), but because of the usual focus on water-column and fine-sediment processes, specific information on bacteria associated with decomposing litter is virtually lacking (but see Findlay et al. 1990, McArthur et al. 1994). Boon (1991) observed that pelagic bacteria were both more abundant and active in an Australian billabong than in the mainstem of their study river. This implies, in combination with the results of the above fungal studies, that compared to streams and rivers the relative importance of bacteria in litter decomposition might increase in lentic floodplain habitats.

One way of assessing the relative importance of bacteria and fungi in decomposition processes consists in determining the productivity of these organisms (Hieber \& Gessner 2002). The underlying assumption is that productivity is proportional to degradative activity. Comparisons of biomass have been used as a first crude measure towards this end (Findlay \& Arsuffi 1989, Baldy et al. 1995), but they will not provide an accurate picture in cases where significant biomass losses co-occur with growth. The contribution of bacteria to leaf decomposition might be underestimated more severely than that of fungi, because losses of bacterial cells from decomposing leaves are likely to exceed losses of fungal mass, which is embedded within the leaf tissue and tends to turn over more slowly. However, the limitation of biomass measurements can be overcome by determining bacterial and fungal productivity and integrating over time, thus taking potential biomass losses into account (Newell et al. 1995, Weyers \& Suberkropp 1996, Baldy \& Gessner 1997). Comparisons of the 2 types of microbial litter decomposers are thus put on a firmer basis. Such productivity estimates can be derived from rates of $\left[{ }^{3} \mathrm{H}\right]$ thymidine or $\left[{ }^{3} \mathrm{H}\right]$ leucine incorporation into DNA or protein for bacteria (e.g. Findlay et al. 1984, Robarts 1998, Kirschner \& Velimirov 1999) and from $\left[{ }^{14} \mathrm{C}\right]$ acetate incorporation rates into ergosterol for fungi (Newell \& Fallon 1991, Suberkropp \& Weyers 1996, Gessner \& Newell 2002).

In the study reported here, we used these methodologies to compare the microbial productivity associated with decomposing leaves in 2 aquatic habitats of a large river system. Our specific objectives were to (1) provide baseline data on microbial productivity associated with allochthonous leaf litter in aquatic habitats; (2) based on estimates of microbial production, assess the relative importance of bacteria and fungi to leaf litter decomposition; (3) track possible shifts in microbial growth dynamics and litter decomposition at 2 contrasting sites of a large river system, the mainstem and an adjacent floodplain pond; and (4) evaluate whether similar patterns of microbial growth and decomposition occur in 2 consecutive years.

\section{MATERIALS AND METHODS}

Study sites. The study was carried out at 2 sites of the Garonne River system in south-western France. The first site was located in the main river channel, $7 \mathrm{~km}$ 

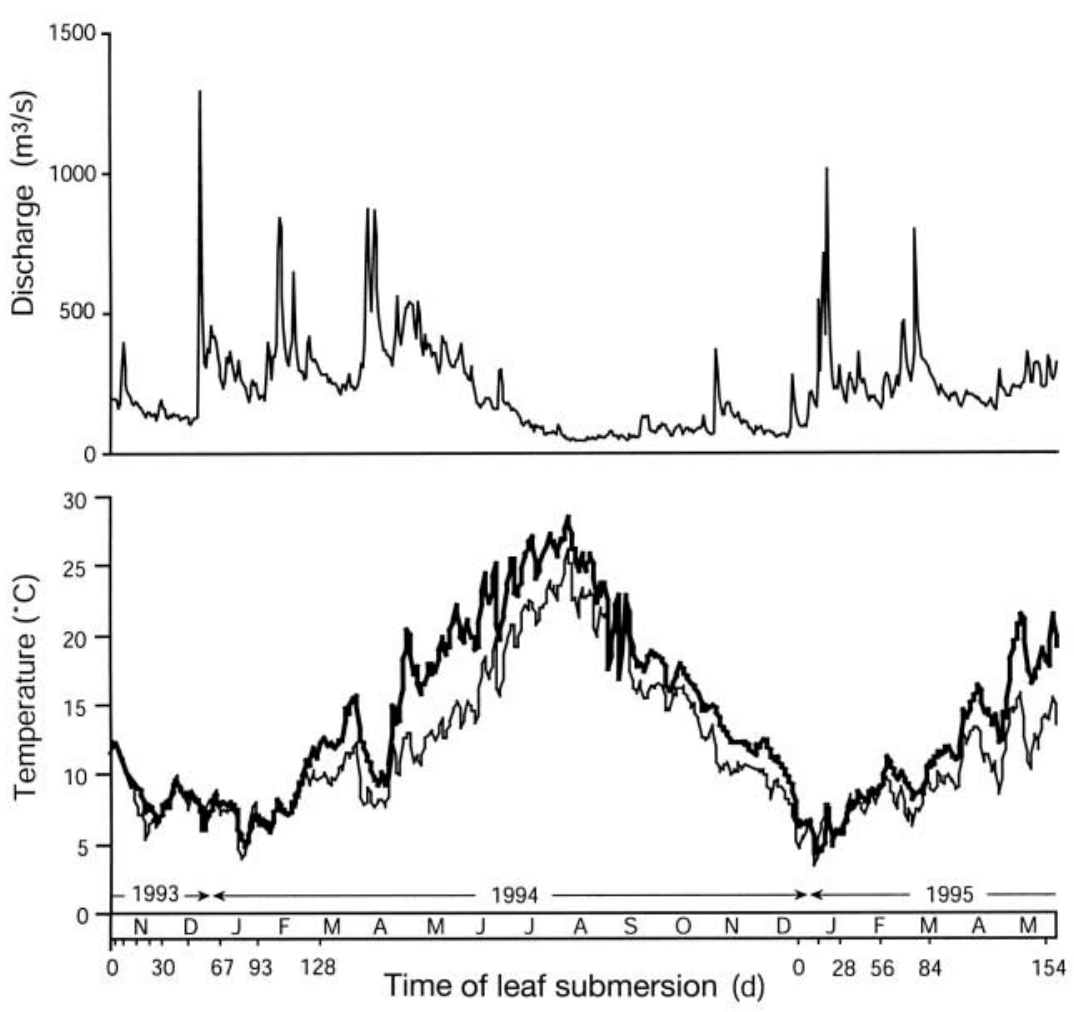

Fig. 1. Daily mean discharge of the mainstem and water temperature of the mainstem (thin line) and floodplain pond (thick line) of the Garonne River system between November 1993 and May 1995. Sampling dates of the litter decomposition experiments are indicated

upstream from the city of Toulouse, where the river is $200 \mathrm{~m}$ wide and seventh order (Baldy et al. 1995). Water depth ranged from about 0.5 to $2 \mathrm{~m}$ during the study. The substratum consisted of pebbles and bedrock. Discharge was recorded at a nearby gauging station (Fig. 1); mean annual values were $200 \pm 12 \mathrm{~m}^{3} \mathrm{~s}^{-1}$, in 1993, 1994 and 1995. The second site was located in a floodplain pond about $180 \mathrm{~m}$ long and $25 \mathrm{~m}$ wide, $3 \mathrm{~km}$ upstream from the first site. Water depth of the pond ranged from 0.2 to $1.5 \mathrm{~m}$, and its bottom consisted primarily of silt. The pond was connected to the main river channel during 8 and $5 \mathrm{~d}$ of floodplain inundation in 1993-94 and 1994-95, respectively. The predominant tree species of the floodplain forest were willow Salix alba L. and poplar Populus gr. nigra L. (and various poplar hybrids).

Water temperatures were recorded every 90 min by Hamster ${ }^{\circledR}$ data loggers (standard model; Elpro-Buchs).
Average daily temperature fluctuated between 3 and $24^{\circ} \mathrm{C}$ at the river site and between 4 and $27^{\circ} \mathrm{C}$ in the floodplain pond (Fig. 1). Water-chemical characteristics at both sites are summarized in Table 1. Oxygen concentrations above the sediment were measured in the field between 07:30 and 10:00 h. Nitrate concentrations were measured by UV spectral deconvolution (Thomas et al. 1993) using an Anthelie 70MI (Secomam) and phosphate concentrations by spectrophotometry with ammonium molybdate (Murphy \& Riley 1962), while all other chemical parameters were determined using standard procedures.

Experimental procedures. Freshly fallen poplar leaves were collected at the study sites in November 1993 and October 1994. Leaves were stored overnight at $4^{\circ} \mathrm{C}$ (1993) or frozen (1994). Leaves were weighed into portions of $13 \mathrm{~g}$ fresh mass and placed in $2.5 \mathrm{~mm}$ mesh bags $(15 \times$ $15 \mathrm{~cm})$. Ten bags were randomly taken to determine the initial leaf dry mass, and 4 of these to estimate the initial fungal and bacterial biomass, production and sporulation (see later sections). The remaining set of bags was split in 2 batches, which were secured at the bottom of the river and pond. Leaves were submerged on 1 November 1993 and on 21 December 1994.

Four bags were retrieved from both sites after 9, 16, $24,30,44,67,93$ and $128 \mathrm{~d}(1993-94)$ and 14, 28, 56, 84

Table 1. Water-chemical characteristics in the mainstem and floodplain pond of the Garonne River system between November 1993 and May 1995 (no. of samples $=18$ )

\begin{tabular}{|c|c|c|c|c|}
\hline \multirow[t]{2}{*}{ Parameter } & \multicolumn{2}{|c|}{ Mainstem } & \multicolumn{2}{|c|}{ Pond } \\
\hline & Mean & Range & Mean & Range \\
\hline $\mathrm{pH}$ & 8.2 & $7.5-8.4$ & 8.3 & $8-8.6$ \\
\hline $\begin{array}{l}\text { Conductivity } \\
\left(\mu \mathrm{Cm}^{-1}, 20^{\circ} \mathrm{C}\right)\end{array}$ & 153 & 110-188 & 458 & $392-574$ \\
\hline $\begin{array}{l}\text { Alkalinity } \\
\left(\mathrm{mg} \mathrm{l}^{-1} \mathrm{CaCO}_{3}\right)\end{array}$ & 45.1 & $10.3-77.0$ & 100.7 & $28.0-187.4$ \\
\hline $\begin{array}{l}\text { Oxygen } \\
\text { (\% saturation) }\end{array}$ & 106 & $98-110$ & 104 & $43-165$ \\
\hline $\begin{array}{l}\mathrm{N}-\mathrm{NO}_{3}^{-} \\
\left(\mathrm{mg} \mathrm{l}^{-1}\right)\end{array}$ & 1.46 & $0.75-2.00$ & 3.34 & $0.82-5.3$ \\
\hline $\begin{array}{l}\mathrm{P}-\mathrm{PO}_{4}{ }^{3-} \\
\left(\mu \mathrm{g} \mathrm{l}^{-1}\right)\end{array}$ & 58.5 & $30.6-97.0$ & 76.5 & $55.4-122.7$ \\
\hline
\end{tabular}


and $154 \mathrm{~d}$ (1994-95) and brought to the laboratory in river or pond water. Leaves were removed from the litter bags and individually rinsed to remove sediments and invertebrates. Portions of the leaf material (see later sections) were taken to determine microbial biomass and production (fungi and bacteria) as well as the spore production and community structure of aquatic hyphomycetes. The remaining leaves were frozen, lyophilized, weighed to the nearest $0.1 \mathrm{mg}$, and ground to pass a $1 \mathrm{~mm}$ mesh screen. Portions of about $250 \mathrm{mg}$ were ashed for $3 \mathrm{~h}$ at $550^{\circ} \mathrm{C}$ to determine the organic matter content.

Fungal community structure and conidial production. Two poplar leaves from each litter bag were placed in $250 \mathrm{ml}$ flasks containing $100 \mathrm{ml}$ of filtered (Whatman GF/D) river or pond water and incubated on a rotary shaker (75 rpm, $25.4 \mathrm{~mm}$ orbital path) for $3 \mathrm{~d}$ at $10^{\circ} \mathrm{C}$. After incubation, $250 \mu \mathrm{l}$ of $0.5 \%$ (w/v) Triton X100 solution was added and $2 \mathrm{ml}$ of the conidial suspension was passed through a membrane filter $(5 \mu \mathrm{m}$ pore size). The conidia trapped on the filter were stained with $0.1 \%$ Trypan blue in $60 \%$ lactic acid, identified and counted at a magnification of 200×. Two filters per sample were prepared and at least 100 conidia per filter were counted. Conidial mass was calculated using published values for the dominant aquatic hyphomycete species encountered in this study (Chauvet \& Suberkropp 1998). The data for these species were also used to establish a relationship between conidial dry mass ( $M$ in fg) and volume ( $V$ in $\mu^{3}$ ) $\left(M=-0.058 V^{2}+641 V\right)$ for calculating the conidial mass of the remaining species. Conidial biovolumes were determined as described in Bärlocher \& Schweizer (1983).

Mycelial biomass and production. Fungal biomass and production associated with leaves were determined on 10 leaf discs (10 mm diameter) from each leaf bag. Discs were placed in vials containing $2.38 \mathrm{ml}$ of an acetate solution prepared in filtered $(0.2 \mu \mathrm{m}$ pore size) river or pond water. The incorporation of radiolabeled acetate was started by adding $120 \mu \mathrm{l}$ of an aqueous sodium $\left[1-{ }^{14} \mathrm{C}\right]$ acetate solution $\left(60 \mathrm{mCi} \mathrm{mmol}^{-1}\right.$; Amersham), to give a final total acetate concentration of $2.5 \mathrm{mM}$. Control vials containing 2 or 3 discs from each replicate leaf bag (10 discs in total) received formaldehyde ( $2 \%$ final concentration) 60 min before the addition of $\left[1-{ }^{14} \mathrm{C}\right]$ acetate. Incubations were carried out for $6 \mathrm{~h}$ at $15^{\circ} \mathrm{C}$ in the dark on a rotary shaker $(350 \mathrm{rpm}$, $3 \mathrm{~mm}$ orbital path). Following the addition of formalin, the leaf discs were removed with forceps and placed onto a membrane filter $(0.45 \mu \mathrm{m}$ pore size), rinsed 3 times with $2 \mathrm{ml}$ of sterile water and stored at $-18^{\circ} \mathrm{C}$. Any conidia produced during the incubation period were thus left in the incubation medium and on the membrane filter.
Leaf discs were lyophilized and weighed to the nearest $0.1 \mathrm{mg}$ before ergosterol was extracted by $30 \mathrm{~min}$ refluxing in alcoholic base and quantified by high pressure liquid chromatography (HPLC) (Gessner et al. 1991). The eluting ergosterol fractions of 3 separate injections from each sample were pooled in a scintillation vial, $10 \mathrm{ml}$ of Ready-Solv EP (Beckman Instruments) was added, and radioactivity measured (Gessner \& Chauvet 1997). Separate experiments were run on 2 occasions to test whether saturation of acetate incorporation and isotope dilution occurred under the chosen experimental conditions. In both cases, saturation was achieved at $2 \mathrm{mM}$ of added acetate and isotope dilution was found to be negligible (data not shown).

Fungal carbon was calculated from ergosterol concentrations using species-specific conversion factors (Gessner \& Chauvet 1993) and assuming 43\% carbon in fungal dry mass (Baldy et al. 1995). To calculate specific production rates (i.e. production/biomass [P/B] ratios), a theoretical conversion factor of $33.05 \mu \mathrm{g}$ ergosterol per $\mu \mathrm{mol}$ of incorporated acetate was used (Gessner \& Chauvet 1997, Gessner \& Newell 2002). This theoretical conversion factor compares well with an empirical factor we determined previously for an aquatic hyphomycete species (Gessner \& Chauvet 1997). It is 2- to 3 -fold lower than conversion factors used by other authors (Suberkropp 1995, Newell 2001), suggesting that our estimates of fungal production and growth may be conservative. Fungal production was calculated by multiplying specific production rate by fungal biomass. For calculating decomposition budgets, measured rates were corrected for temperature using a $Q_{10}$ of $1.99 \pm 0.19$ (mean \pm SD) determined from growth of 6 dominant species that accounted for about $80 \%$ of the conidia released from leaves (Table 2; M. Thomas \& E. Chauvet unpubl. data). Cumulative fungal production was calculated by relating temperature-adjusted production values to a standard amount (1 g) of initial leaf carbon, interpolating linearly between sampling dates, and summing up over the study period.

Bacterial biomass and production. Bacterial production associated with leaves was estimated from rates of $\left[{ }^{3} \mathrm{H}\right]$ thymidine incorporation into DNA following a protocol based on Findlay et al. (1984) and Palumbo et al. (1987). Two leaves from each mesh bag were placed in a sterile plastic bag containing $40 \mathrm{ml}$ of filter-sterilized water. Bacteria were dislodged from the leaf material with a Stomacher 80 Lab-Blender (Seward Medical) set at normal speed (10 min treatment). The resultant suspension was strained through a $5 \mu \mathrm{m}$ nylon screen to remove the largest particles, and the bag and screen rinsed with $10 \mathrm{ml}$ of filter-sterilized water. The percentage of bacteria associated with the particles that were retained on the screen was typically 0 to $3 \%$. 
A $10 \mathrm{ml}$ aliquot of the combined suspensions was preserved with formalin ( $2 \%$ final concentration) and stored for later bacterial counts and biovolume determinations (see below).

Additional $3 \mathrm{ml}$ aliquots of the suspension were placed in sterile tubes and incubated with radiolabeled thymidine. Preliminary experiments had shown that saturation of thymidine incorporation did not occur up to a concentration of at least $400 \mathrm{nM}$; therefore, isotope dilution was determined at each sampling date (Servais 1990). Seven concentrations of thymidine were prepared in membranefiltered $(0.2 \mu \mathrm{m}$ pore size) river or pond water: 20, 30, 50, 100, 200, 300 and $400 \mathrm{nM}$, with $20 \mathrm{nM}$ of [methyl$\left.{ }^{3} \mathrm{H}\right]$ thymidine $\left(50 \mu \mathrm{Ci} \mathrm{nmol}{ }^{-1}\right.$; ICN Biomedicals) added. Five control tubes with total thymidine concentrations between 20 and $400 \mathrm{nM}$ received trichloracetic acid (TCA) to a final concentration of $5 \%$ before labeled thymidine was added. Samples were incubated for $20 \mathrm{~min}$ at $15^{\circ} \mathrm{C}$ on a rotary shaker (350 rpm, $3 \mathrm{~mm}$ orbital path). Thymidine incorporation was stopped by adding TCA and immediately placing the tubes on ice for at least $12 \mathrm{~h}$. The precipitate was then collected on a polycarbonate filter $(0.45 \mu \mathrm{m}$ pore size; Costar Europe) and rinsed 3 times with $5 \%$ TCA. Filters were placed in scintillation vials and $0.5 \mathrm{ml}$ of $0.5 \mathrm{M} \mathrm{HCl}$ was added before heating at 95 to $100^{\circ} \mathrm{C}$ for $30 \mathrm{~min}$. After cooling, $10 \mathrm{ml}$ of Ready Protein (Beckman Instruments) was added, and the radioactivity was determined.

Thymidine incorporation rates were corrected for isotope dilution using linear regression analysis (Servais 1990). The ratio of added radioactivity to measured radioactivity was plotted against the total thymidine concentration added, and the incorporation rate was calculated as the reciprocal value of the slope of the regression line. Most regressions were highly significant ( $p<0.001$ ), with coefficients of determination ranging from 0.73 to 0.99 . Bacterial carbon production was calculated using a conversion factor of $4 \times 10^{18}$ bacterial cells per mole of incorporated thymidine (Fallon \& Newell 1986), and the carbon content of bacterial cells was estimated from measured biovolumes according to the empirical relationship, $C=89.6 \times$ $V^{0.59}$, where $V$ is the cell volume in $\mu^{3}$ and $C$ the cell carbon content in fg (Baldy et al. 1995).
Bacterial biomass was determined in 10- or 100-fold diluted aliquots of formaldehyde preserved suspensions (10 ml final volume). Bacteria were stained with DAPI (4',6-diamidino-2-phenylindole; $5 \mu \mathrm{g} \mathrm{ml}^{-1}$ ), filtered through a black polycarbonate membrane, and counted at 1000× magnification with an Axioplan (Zeiss) epifluorescence microscope. To determine bacterial biovolumes, photographs were taken from filter portions (Ektachrome ISO 400/278; Kodak), projected onto a screen, and 100 to 200 bacteria were measured and assigned to shape and size classes (Baldy et al. 1995). Specific production rates were calculated as the quotient of bacterial production and biomass and temperature-adjusted (assumed a $Q_{10}$ of 2) for calculating decomposition budgets.

Statistical analysis. Leaf breakdown coefficients $(k)$ were calculated by adjusting the mass loss data to the simple exponential model $m_{t}=m_{0} \times \mathrm{e}^{-k t}$, where $m_{t}$ is the leaf mass remaining at time $t$ and $m_{0}$ is the initial leaf mass (Wieder \& Lang 1982). The same approach was used to determine $k$ values on a degree-day basis. Differences in breakdown coefficients (determined 
from linear regression of ln-transformed data) between sites and years were tested using analysis of covariance (ANCOVA) (Boulton \& Boon 1991). Analysis of variance (ANOVA) was used to test for differences between sites in terms of bacterial and fungal biomass and production as well as sporulation rate and conidial production. Analyses were conducted separately for both years. Data were ln-transformed when test assumptions were not met (i.e. mycelial biomass in 1993 and sporulation rate in 1994). p-values <0.05 were considered to be significant. Calculations of exponential breakdown coefficients and ANCOVA were made using SYSTAT (Wilkinson 1990) and ANOVA was carried out using the statistical software package Minitab (release 13 for Windows 2000, Minitab).

\section{RESULTS}

\section{Fungal biomass, production and sporulation}

Fungal biomass increased rapidly within the first weeks after submersion of leaves at the river site, reaching peaks of 8 (1993) and 5\% (1994) of detrital carbon (Fig. 2). In the floodplain pond, fungal biomass increased more slowly, reaching maximal values of only $2 \%$ of detrital carbon, and remained significantly lower than in the river channel throughout the experiments (ANOVA, p < 0.001). Differences in fungal biomass between years were significant in the river (ANOVA, $\mathrm{p}=0.02$ ) but not in the floodplain pond.

Specific production rates $(\mathrm{P} / \mathrm{B})$ of fungi ranged from 0.004 to $0.1 \mathrm{~d}^{-1}$ (Fig. 3A,B) with significantly higher rates observed in the floodplain pond after the first month of leaf submersion (ANOVA, p $<0.001$ ).

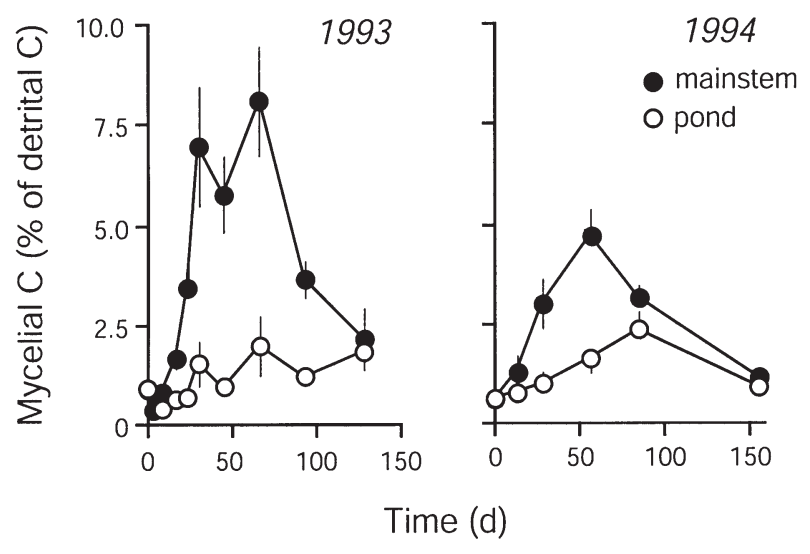

Fig. 2. Changes in mycelial biomass associated with leaf litter decomposing in the mainstem and floodplain pond of the Garonne River system in 2 consecutive years. Bars denote $\pm 1 \mathrm{SE}(\mathrm{n}=4)$
Mycelial production increased initially in both sites and years and then decreased (Fig. 3C,D). Peaks occurred later in the pond in both 1993 and 1994.

Differences between fungal biomass and cumulative production increased as leaf decomposition proceeded (Fig. 4A,B), and the maximum ratio between the 2 measures was higher in the floodplain pond (14) than in the river (9).

Sporulation rates of aquatic hyphomycetes showed markedly different patterns between sites (Fig. 3E,F). In the main channel, sporulation activity was highest initially and then declined, whereas in the floodplain pond sporulation was barely detectable during the first 1 to 2 mo of leaf submersion and then increased to $>0.2$ conidia per $\mu \mathrm{g}$ of detrital $\mathrm{C}$ per day. Overall, the sporulation rate of aquatic hyphomycetes was significantly higher at the river site in both years (ANOVA, $\mathrm{p}<0.001$ ). The sum of cumulated conidial and mycelial production (Fig. 4A,B) was almost the same in the mainstem and floodplain pond, with about $70 \mathrm{mg}$ of fungal biomass produced after $154 \mathrm{~d}$.

Twenty-one species of aquatic hyphomycetes were found sporulating on leaves in the river channel, compared to 16 species in the floodplain pond (Table 2). At the river site, 7 species accounted for $>90 \%$ of the total conidial mass released from decomposing leaves, whereas in the floodplain pond only 2 species were responsible for almost the entire conidial output (Table 2). The species composition of fungal assemblages and the relative abundance of single species differed greatly between sites but were remarkably similar within sites between years. The temporal patterns of conidial production in terms of mass only partly reflected changes in sporulation rates (Fig. 3G,H). This result was caused by shifts in community composition that occurred over time coupled with notable size differences among species. These variations resulted in a somewhat erratic temporal pattern of conidial production in 1993, particularly at the river site. In terms of conidial output, Anguillospora longissima dominated the fungal assemblage in the floodplain pond, whereas Clavariopsis aquatica was the dominant species in the river channel, followed by A. longissima.

\section{Bacterial biomass and production}

Dynamics of bacterial densities and biomass associated with leaves were similar at both sites. Differences between years were greater, possibly as a result of some differences in the experimental procedures used in 1993-94 and 1994-95 (Fig. 5). Bacterial numbers and biomass nevertheless reached similar levels in both years and sites $\left(13 \times 10^{9}\right.$ to $24 \times 10^{9}$ cells per $\mathrm{g}$ of detrital $\mathrm{C}$, equivalent to about $0.5 \mathrm{mg} \mathrm{C}$ per $\mathrm{g}$ of detri- 

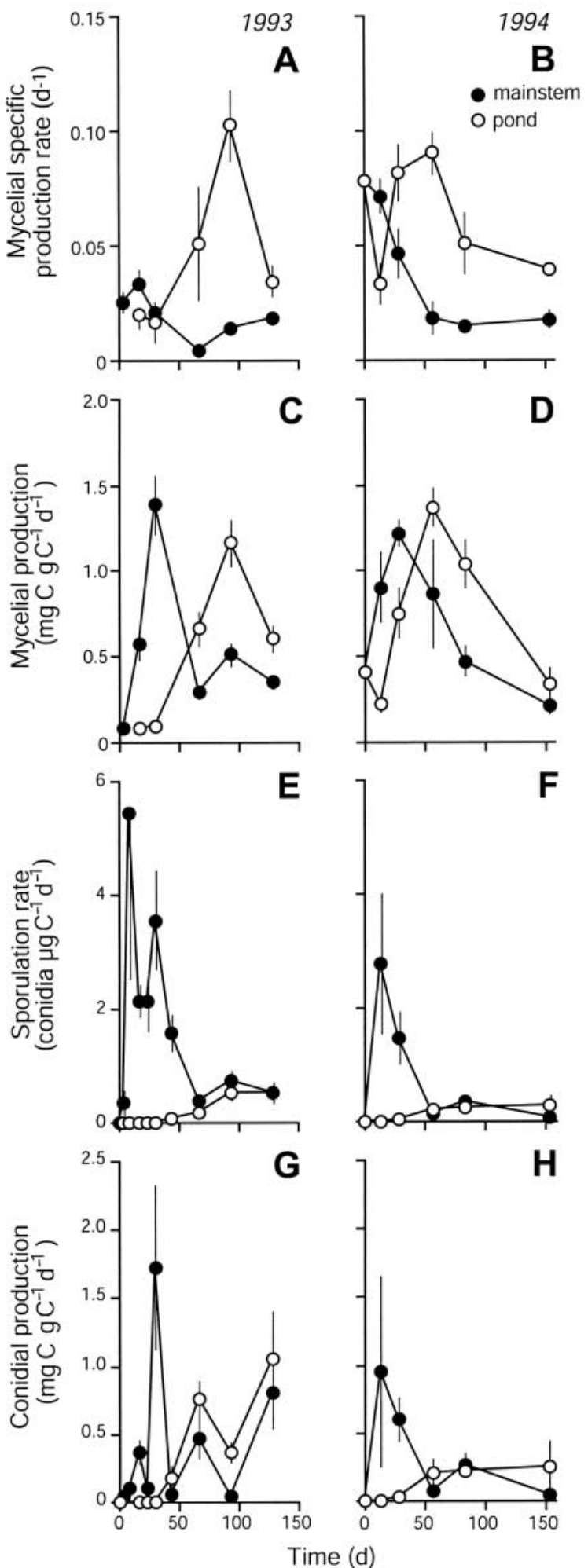

Fig. 3. $(A, B)$ Dynamics of specific mycelial production rate (daily $\mathrm{P} / \mathrm{B}$ values), $(\mathrm{C}, \mathrm{D})$ mycelial production, $(\mathrm{E}, \mathrm{F})$ sporulation rate and $(G, H)$ conidial production of fungi associated with decomposing leaf litter in the mainstem and a floodplain pond of the Garonne River system in 2 consecutive years. Bars denote \pm 1 SE $(n=4)$
1994
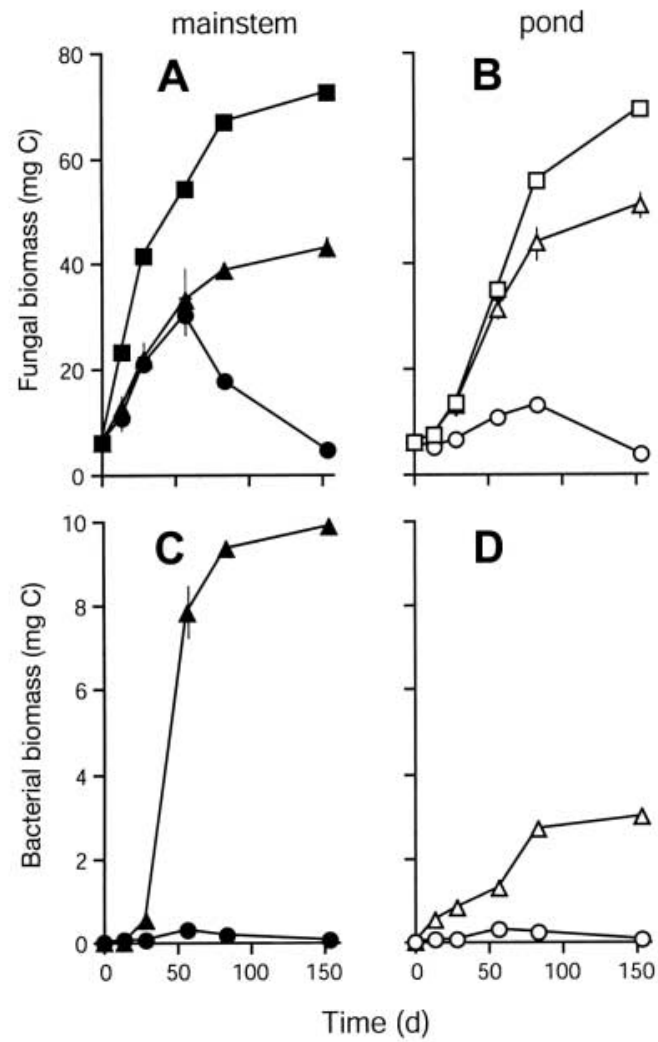

Fig. 4. Comparison of cumulative microbial production with actually observed biomass on decomposing leaves in the mainstem $(\mathrm{A}, \mathrm{C})$ and a floodplain pond $(\mathrm{B}, \mathrm{D})$ of the Garonne River system in 1994-95. $(\boldsymbol{\Delta}, \Delta)$ Cumulative production values derived from instantaneous production rates $\left(\left[{ }^{14} \mathrm{C}\right]\right.$ actetate (fungi) and $\left[{ }^{3} \mathrm{H}\right]$ thymidine (bacteria) incorporation); $(\mathbf{\square}, \square)$ cumulative production values that include the separately determined conidial production; $(\bullet, 0)$ actually observed biomass. All values refer to $1 \mathrm{~g}$ of litter ash-free dry mass present before leaves were submerged. Bars denote \pm 1 SE $(n=4)$

tal C) with a tendency to decrease towards the end of experiments. However, the decreasing trend was not observed in the floodplain pond in 1993, resulting in a significantly higher bacterial biomass on the last sampling dates at this site (ANOVA, p < 0.001). Bacterial biomass accounted for 0 to $11 \%$ of the total microbial biomass made up by fungi (Fig. 2) and bacteria (Fig. 5).

Bacterial production was only measured in 1994 (Fig. 6). Specific production rates were highest initially (about 1.1 to $1.5 \mathrm{~d}^{-1}$ ) and then tended to decline, with overall higher values in the river channel. Bacterial carbon production was generally similar at both sites; however, after $8 \mathrm{wk}$, production had increased greatly on leaves submerged in the river mainstem, resulting in a 10-fold higher production than in the floodplain pond (ANOVA, p < 0.001). 

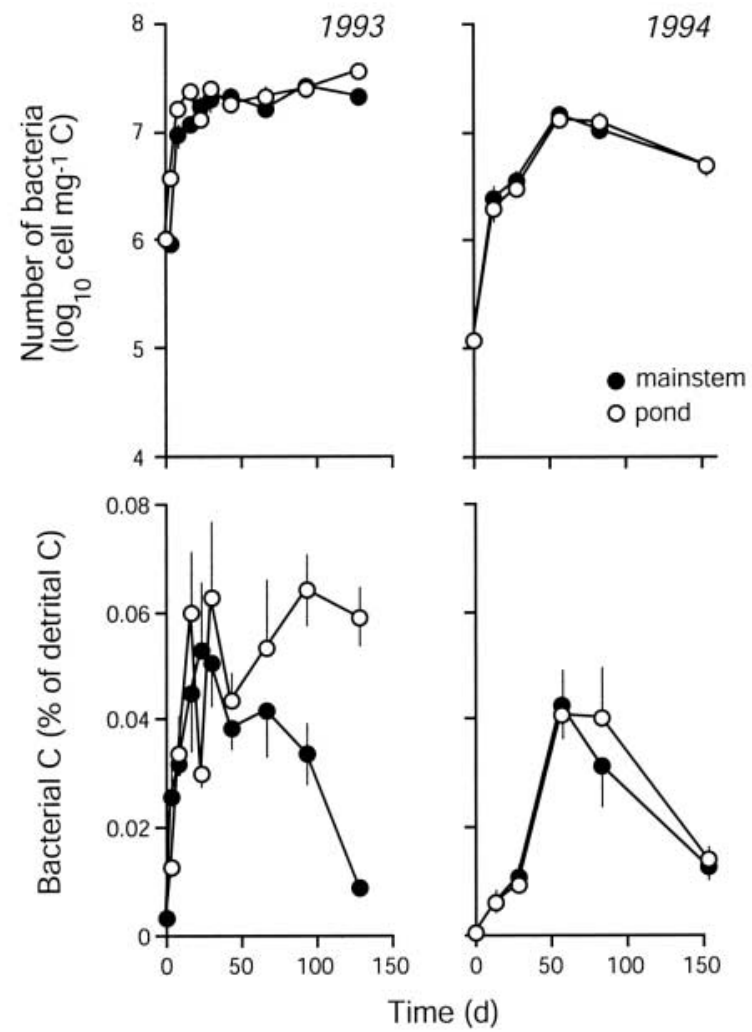

Fig. 5. Changes in bacterial numbers and biomass associated with leaf litter decomposing in the mainstem and floodplain pond of the Garonne River system in 2 consecutive years. Bars denote \pm 1 SE $(\mathrm{n}=4)$

1994
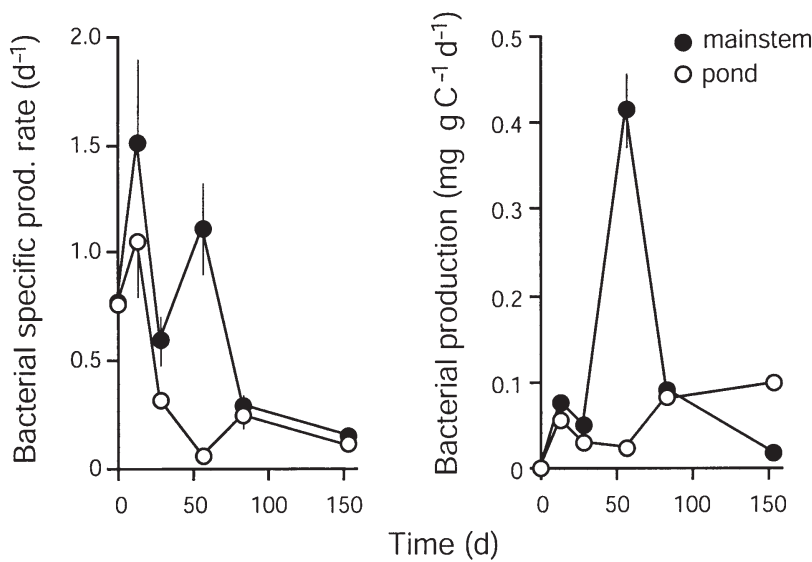

Fig. 6. Dynamics of bacterial-specific production rate (daily $\mathrm{P} / \mathrm{B}$ values) and production associated with leaf litter decomposing in the mainstem and floodplain pond of the Garonne River system in 1994. Bars denote \pm 1 SE $(n=4)$
Table 3. Exponential breakdown coefficients (mean \pm asymptotic SE) of poplar leaves decomposing in the mainstem and floodplain pond of the Garonne River system in 1993 (no. of species $=36$ ) and 1994 (no. of species $=20) ; k$ (leaf breakdown coefficients) values calculated on a daily basis $\left(\mathrm{d}^{-1}\right)$ and $k^{\prime}$ values on a degree-day $\left(\mathrm{dd}^{-1}\right)$ basis

\begin{tabular}{|lccr|}
\hline Site & Year & $k\left(\mathrm{~d}^{-1}\right)$ & \multicolumn{1}{c|}{$k^{\prime}\left(\mathrm{dd}^{-1}\right)$} \\
\hline Mainstem & 1993 & $0.0085 \pm 0.0009$ & $00108 \pm 0.00005$ \\
Pond & 1993 & $0.0077 \pm 0.0007$ & $0.00090 \pm 0.00003$ \\
Mainstem & 1994 & $0.0071 \pm 0.0005$ & $0.00091 \pm 0.00003$ \\
Pond & 1994 & $0.0070 \pm 0.0006$ & $0.00079 \pm 0.00003$ \\
& & & \\
\hline
\end{tabular}

Differences between bacterial biomass and cumulative production increased during leaf submersion at both sites (Fig. 4C,D), and particularly in the river channel. The maximum ratio between the 2 measures reached almost 200 in the mainstem but only 12 in the floodplain pond.

\section{Leaf mass loss}

Decomposition rates varied within a range lower than $\pm 9 \%$ (Table 3 ) and were found to be similar between both years and sites (ANCOVA; $p$ > 0.75). Of the initial litter mass, 44 and $39 \%$ remained at the end of experiments, after 128 and 154 d in 1993 and 1994, respectively.

\section{DISCUSSION}

\section{Comparison of flowing and stagnant water environments}

The rates of leaf breakdown in the mainstem and floodplain pond of the Garonne River system were similar, whereas the dynamics of the microorganisms colonizing the leaves at both sites partly differed. Specifically, the 2- to 3-fold greater fungal biomass in leaves at the riverine site did not result in a significantly faster decomposition of leaves. This finding is in contrast to observations made in headwater streams, where leaf decomposition rates have been found to be positively correlated with maximum fungal biomass (Gessner \& Chauvet 1994, Suberkropp \& Chauvet 1995, Maharning \& Bärlocher 1996, Gessner et al. 1997). In contrast to the substantial difference in fungal biomass between the 2 sites, fungal production was similar, suggesting the difference in biomass was due to greater losses in standing water (e.g. due to selective feeding of detritivorous invertebrates on leaf areas colonized by fungi; cf. Arsuffi \& Suberkropp 1985). If 
one assumes a growth efficiency of $35 \%$ (Suberkropp 1991), fungi growing in leaves in the pond would account for $49 \%$ of the total leaf mass loss observed in litter bags. This compares to an estimated fungal contribution of $41 \%$ in the river channel and suggests that fungi may be important agents of allochthonous litter decomposition in standing water bodies of fluvial systems, as has been observed in some lotic habitats (see Gessner 1997, Gessner et al. 1997, Suberkropp 1998a).

Although highest diversity of aquatic hyphomycetes has been reported from clear fast flowing headwater streams (Bärlocher 1992, Suberkropp 1992, Garnett et al. 2000), these fungi are also capable of extensive leaf colonization in larger rivers (Chergui \& Pattee 1988, Baldy et al. 1995), and this is confirmed by the present results. In contrast, fungal assemblages in standing water bodies, including floodplain ponds (Chergui \& Pattee 1988), are thought to be dominated by other types of fungi (e.g. the so-called aero-aquatic hyphomycetes; Webster \& Descals 1981). The lower diversity of aquatic hyphomycetes in the floodplain pond compared to the Garonne River (Table 2) and other streams in south-western France (Chauvet 1991, Gessner et al. 1993) at first glance may seem to be in line with this idea. However, the presence of as many as 16 species and the appreciable sporulation of at least 2 of them indicates that aquatic hyphomycetes were an active component of leaf-associated microbial assemblage even in the standing-water habitat. This finding is in contrast to observations made in an oxbow lake of another larger river in France (Chergui \& Pattee 1988). Whether it reflects a certain 'fluvial character' of the pond examined in the Garonne floodplain, due to upwelling groundwater and/or temporary surface or subsurface hydrologic connections to the river (possibly providing fungal propagules, destroying gradients and supplying dissolved oxygen and nutrients), requires further investigation. It appears nevertheless that apart from the fine sediments and the absence of a constant directional flow, the physical-chemical conditions were not particularly unfavorable to aquatic hyphomycetes (Table 1).

Variables describing the bacterial assemblages on leaves likewise showed little difference between the lentic and lotic sites. Mean bacterial biovolumes decreased gradually from $0.16 \mu^{3}$ to about half that value as decomposition proceeded, but they did not differ between sites. The relative abundance of bacterial morphotypes was also nearly identical throughout the experiments. Rods in the size range of 0.01 to $0.10 \mu^{3}$ increased at both sites from 30 to $90 \%$, whereas the proportions of the 8 other morphotypes all decreased. Cumulative bacterial carbon production in the river was 3.7-fold higher than in the floodplain pond $i$ however, this difference was caused by a single extreme production rate and should hence not be overinterpreted. If this exceptional value is ignored, the difference between sites becomes level. These data suggest that the bacterial assemblages associated with decomposing leaves did not deviate greatly between the 2 contrasting study sites. Some compositional differences of the bacterial assemblages may nevertheless have gone undetected, because the morphological criteria used in this study only allowed a limited resolution of bacterial community structure.

\section{Comparison between years}

The magnitude and temporal dynamics of microbial growth parameters (Figs. 3 \& 5) did not vary greatly in the 2 consecutive years (1993 and 1994) examined in this study, both in the mainstem of the Garonne River and the floodplain pond. Moreover, fungal biomass associated with poplar leaves in the mainstem was as high as the biomass found previously (1991) in the same type of litter in this environment (Baldy et al. 1995). This is a first indication that fungal colonization dynamics at a given site, in terms of both composition and productivity, may not vary greatly among years. Longer-term studies at multiple sites are required to verify this tentative conclusion.

In spite of the overall similar patterns between years, peak values of microbial biomass were slightly delayed and/or lower in 1994-95, and leaf decay rates were also slightly reduced ( $p=0.04$ at the river site). The difference in average temperature resulting from the delayed start of the experiment in 1994 (Fig. 1) cannot be the explanation because the between-year differences persist even when the decay rates are temperature-normalized by calculating them as a function of thermal sums $\left(k^{\prime}\right.$ : leaf breakdown coefficient in degree-day ${ }^{-1}$; Table 3). It must be borne in mind, however, that even though average temperatures were similar, the temperature regimes differed between years, and the flooding regimes were also different; both factors could have induced changes in microbial community structure (e.g. the disappearance of Lunulospora curvula as initial temperatures dropped; cf. Bärlocher 1992, Gessner 1997) and performance on leaves.

\section{Microbial growth characteristics in decomposing litter}

Specific production rates (P/B) of the leaf-colonizing fungi in the present study (peaks of 0.033 to $0.102 \mathrm{~d}^{-1}$ ) fall within the range of values observed in other aquatic environments (see compilations in Gessner 1997, Suberkropp 2001). Maximum specific production 
rates of 0.02 to $0.17 \mathrm{~d}^{-1}$ have been measured in decomposing grass, sedge and rush leaves in freshwater marshes (Newell et al. 1995, Komínková et al. 2000, Kuehn et al. 2000) and values between 0.02 and $0.20 \mathrm{~d}^{-1}$ have been found associated with tree leaves from small streams (Suberkropp 1995, 1997, 2001, Weyers \& Suberkropp 1996, Baldy \& Gessner 1997 , Gessner \& Chauvet 1997). These rates correspond to maximum turnover times of 5 to $50 \mathrm{~d}$ in general and 10 to $30 \mathrm{~d}$ in the Garonne River system, and indicate a remarkable growth potential of aquatic litter fungi.

Peaks in production rates $(1.2$ to $1.4 \mathrm{mg} \mathrm{C}$ per $\mathrm{g}$ of detrital $\mathrm{C}$ per day) are also intermediate between values reported from other aquatic environments (overall range of 0.24 to $16 \mathrm{mg} \mathrm{C}$ per $\mathrm{g}$ of detrital C per day (Newell et al. 1995, Suberkropp 1995, 1997, Weyers \& Suberkropp 1996, Gessner \& Chauvet 1997, Komínková et al. 2000, Kuehn et al. 2000). A large portion of this production was apparently allocated to reproductive structures, particularly in the mainstem of the Garonne River, as is suggested by the high rates and temporal patterns of conidial production (Figs. 3 $\& 4 \mathrm{~A}, \mathrm{~B})$. This reflects the capacity of aquatic hyphomycetes to occupy and exploit submerged leaf litter rapidly and to allocate the assimilated resources to reproductive structures early in their life cycle (Suberkropp 1991, 1995, 1998b, Maharning \& Bärlocher 1996, Gessner \& Chauvet 1997). This feature of aquatic hyphomycetes is well known and appears to be a key element ensuring the success of these fungi in running water environments. Dispersal of the propagules in standing water environments must nevertheless occur by mechanisms other than transport with the downstream flow.

The relative delay in mycelial and conidial production observed in the floodplain pond may reflect a specific response of the dominant sporulating species, Anguillospora longissima and A. filiformis, to the stagnant-water environment. Resource availability for fungi is clearly less variable in time in the lentic habitat than in the main river channel, where litter may be easily flushed downstream during high-discharge events. The delayed sporulation in the floodplain pond appears to have been triggered by environmental conditions rather than being due to intrinsic properties of the 2 species, since in pure culture both A. longissima and $A$. filiformis start to sporulate as early as other aquatic hyphomycetes, including some of the dominants in the Garonne River (Suberkropp 1991, Chauvet \& Suberkropp 1998).

The bacterial turnover times of 0.5 to $12.4 \mathrm{~d}$ in the Garonne River system are well within the range of values derived from thymidine incorporation into litterassociated bacteria in other freshwater environments (Findlay \& Arsuffi 1989, Moran \& Hodson 1989,
Sinsabaugh \& Findlay 1995, Baldy \& Gessner 1997, Thomaz \& Esteves 1997). The method used in the present study, i.e. dislodging bacteria from their leaf substrate before thymidine incorporation, thus appears to provide data comparable to those based on other approaches. Production values obtained with the $\left[{ }^{3} \mathrm{H}\right]$ leucine method also fall within this range (Moran \& Hodson 1992, Thomaz \& Wetzel 1995, Weyers \& Suberkropp 1996, Kuehn et al. 2000) and point to a rapid turnover of bacteria associated with submerged decomposing litter. The rather large discrepancy observed between bacterial biomass and cumulative production, even when one extreme production estimate is discarded (Fig. 4C,D), further supports this idea. What remains unclear, however, is which are the critical processes that govern the massive bacterial losses from decomposing leaves, protozoan grazing, phage lysis, autolysis, or simply abrasion?

\section{Contribution of fungi and bacteria to litter breakdown}

The substantially higher biomass of fungi compared to that of bacteria observed in this study is consistent with results from investigations in other litter decomposition systems in freshwater (Findlay \& Arsuffi 1989, Baldy et al. 1995, Newell et al. 1995, Suberkropp \& Weyers 1996, Baldy \& Gessner 1997, Komínková et al. 2000, Kuehn et al. 2000, Hieber \& Gessner 2002). Although differences were slightly less pronounced in the floodplain pond, the same general trend was apparent in both sites and years. It has been argued, however, that the small proportion of bacterial biomass may not correspond to a small contribution to decomposition, because biomass determinations are likely to underestimate bacterial production and activity (Findlay \& Arsuffi 1989, Baldy et al. 1995, Weyers \& Suberkropp 1996, Baldy \& Gessner 1997, Gessner 1997). Indeed, on leaves submerged in the mainstem of the Garonne River, bacteria accounted for up to $32 \%$ of the total microbial carbon production (on Day 56 in 1994), even though they made up less than $1 \%$ of the total microbial biomass at this time. Similar trends have been observed on leaves decomposing in a small lowland stream (Weyers \& Suberkopp 1996) and in freshwater marshes (Newell et al. 1995, Kuehn et al. 2000). In all of these studies, however, fungi were generally maintained at a higher proportion in the microbial assemblages even on a production basis and even at advanced stages of litter decomposition, when bacteria typically become relatively more important. The fungal predominance was accentuated in the floodplain pond with a bacterial contribution to total microbial production of only $6 \%$, despite a relatively higher 
biomass of bacteria compared to the river ( $3 \%$ instead of $1 \%$ of the total microbial biomass). Thus, although bacteria may be of greater significance in leaf decomposition than has been predicted based on estimates of litter-associated biomass, our comparative analysis of fungal and bacterial productivity corroborates the importance of fungi, even on leaves submerged in a river floodplain pond.

Acknowledgements. We are grateful to Corinne Calvo, Aimé Pech, Fabrice Combes, Marie-Françoise Patau-Albertini and Eric Fabre for field and/or laboratory assistance, Jacques Belliard for statistical advice, and 3 anonymous reviewers for comments on the manuscript. This work was supported by the Centre National de la Recherche Scientifique (CNRS) and the European Commission (ERMAS project, contract EV5VCT920100).

\section{LITERATURE CITED}

Arsuffi TL, Suberkropp K (1985) Selective feeding by stream caddisfly (Trichoptera) detritivores on leaves with fungalcolonized patches. Oikos 45:50-58

Baldy V, Gessner MO (1997) Towards a budget of leaf litter decomposition in a first-order woodland stream. C R Acad Sci Paris Sér III 320:747-758

Baldy V, Gessner MO, Chauvet E (1995) Bacteria, fungi, and the breakdown of leaf litter in a large river. Oikos 74 : 93-102

Bärlocher F (1992) The ecology of aquatic hyphomycetes. Ecological studies, Vol 94. Springer-Verlag, Berlin

Bärlocher F, Schweizer M (1983) Effects of leaf size and decay rate on colonization by aquatic hyphomycetes. Oikos 41 : 205-210

Boon PI (1991) Bacterial assemblages in rivers and billabongs of southeastern Australia. Microb Ecol 22:27-52

Boulton AJ, Boon PI (1991) A review of methodology used to measure leaf litter decomposition in lotic environments: time to turn over an old leaf? Aust J Mar Freshw Res 42: $1-43$

Chauvet E (1988) Influence of the environment on willow leaf litter decomposition in the alluvial corridor of the Garonne River. Arch Hydrobiol 112:371-386

Chauvet E (1991) Aquatic hyphomycete distribution in southwestern France. J Biogeogr 18:699-706

Chauvet E, Jean-Louis AM (1988) Production de litière de la ripisylve de la Garonne et apport au fleuve. Acta Oecol Oecol Gen 9:265-279

Chauvet E, Suberkropp K (1998) The influence of temperature on sporulation of aquatic hyphomycetes. Appl Environ Microbiol 64:1522-1525

Chergui H, Pattee E (1988) The dynamics of Hyphomycetes on decaying leaves in the network of the River Rhone (France). Arch Hydrobiol 114:3-20

Chergui H, Pattee E (1990) The processing of leaves of trees and aquatic macrophytes in the network of the River Rhone. Int Rev Ges Hydrobiol 75:281-302

Cuffney TF (1988) Input, movement and exchange of organic matter within a subtropical coastal blackwater river-floodplain system. Freshw Biol 19:305-320

Fallon RD, Newell SY (1986) Thymidine incorporation by the microbial community of standing dead Spartina alterniflora. Appl Environ Microbiol 52:1206-1208
Findlay SEG, Arsuffi TL (1989) Microbial growth and detritus transformations during decomposition of leaf litter in a stream. Freshw Biol 21:261-269

Findlay SEG, Meyer JL, Edwards RT (1984) Measuring bacterial production via rate of incorporation of $\left[{ }^{3} \mathrm{H}\right]$ thymidine into DNA. J Microbiol Methods 2:57-72

Findlay SEG, Howe K, Austin HK (1990) Comparison of detritus dynamics in two tidal freshwater wetlands. Ecology 71 : 288-295

Garnett H, Bärlocher F, Giberson D (2000) Aquatic hyphomycetes in Catamaran Brook: colonization dynamics, seasonal patterns, and logging effects. Mycologia 92: $29-41$

Gessner MO (1997) Fungal biomass, production and sporulation associated with particulate organic matter in streams. Limnetica 13:33-44

Gessner MO, Chauvet E (1993) Ergosterol-to-biomass conversion factors for aquatic hyphomycetes. Appl Environ Microbiol 59:502-507

Gessner MO, Chauvet E (1994) Importance of stream microfungi in controlling breakdown rates of leaf litter. Ecology 75:1807-1817

Gessner MO, Chauvet E (1997) Growth and production of aquatic hyphomycetes in decomposing leaf litter. Limnol Oceanogr 42:496-505

Gessner MO, Newell SY (2002) Biomass, growth rate, and production of filamentous fungi in plant litter. In: Crawford RL, Hurst CJ, Knudsen GR, McInerney MJ, Stetzenbach LD (eds) Manual of environmental microbiology. American Society for Microbiology, Washington, DC (in press)

Gessner MO, Bauchrowitz MA, Escautier M (1991) Extraction and quantification of ergosterol as a measure of fungal biomass in leaf litter. Microb Ecol 22:285-291

Gessner MO, Thomas M, Jean-Louis AM, Chauvet E (1993) Stable successional patterns of aquatic hyphomycetes on leaves decaying in a summer cool stream. Mycol Res 97: $163-172$

Gessner MO, Suberkropp K, Chauvet E (1997) Decomposition of plant litter by fungi in marine and freshwater ecosystems. In: Wicklow DT, Söderström B (eds) The Mycota: a comprehensive treatise on fungi as experimental systems for basic and applied research, Vol 4. Springer-Verlag, Berlin, p 303-322

Hieber M, Gessner MO (2002) Contribution of stream detrivores, fungi and bacteria to leaf breakdown based on biomass estimates. Ecology 83:1026-1038

Kirschner AKT, Velimirov B (1999) Benthic bacterial secondary production measured via simultaneous ${ }^{3} \mathrm{H}$-thymidine and ${ }^{14} \mathrm{C}$-leucine incorporation, and its implication for the carbon cycle of a shallow macrophyte-dominated backwater system. Limnol Oceanogr 44:1871-1881

Komínková D, Kuehn KA, Büsing N, Steiner D, Gessner MO (2000) Microbial biomass, growth, and respiration associated with submerged litter of Phragmites australis decomposing in a littoral reed stand of a large lake. Aquat Microb Ecol 22:271-282

Kuehn KA, Lemke MJ, Suberkropp K, Wetzel RG (2000) Microbial biomass and production associated with decaying leaf litter of the emergent macrophyte Juncus effusus. Limnol Oceanogr 45:862-870

Maharning AR, Bärlocher F (1996) Growth and reproduction in aquatic hyphomycetes. Mycologia 88:80-88

Maltby L (1992) Heterotrophic microbes. In: Calow P, Petts GE (eds) The rivers handbook: hydrological and ecological principles, Vol 1. Blackwell, Oxford, p 165-194

Mayack DT, Thorp JH, Cothran M (1989) Effects of burial and 
floodplain retention on stream processing of allochthonous litter. Oikos 54:378-388

McArthur JV, Aho JM, Rader RB, Mills GL (1994) Interspecific leaf interactions during decomposition in aquatic and floodplain ecosystems. J Nat Am Benthol Soc 13:57-67

Moran MA, Hodson RE (1989) Bacterial secondary production on vascular plant detritus: relationships to detritus composition and degradation rate. Appl Environ Microbiol 55: $2178-2189$

Moran MA, Hodson RE (1992) Contributions of three subsystems of a freshwater marsh to total bacterial secondary productivity. Microb Ecol 24:161-170

Murphy J, Riley J (1962) A modified single solution method for the determination of phosphate in natural waters. Anal Chim Acta 27:31

Naiman RJ, Decamps H (1997) The ecology of interfaces: riparian zones. Annu Rev Ecol Syst 28:621-658

Newell SY (2001) Multiyear patterns of fungal biomass dynamics and productivity within naturally decaying smooth cordgrass shoots. Limnol Oceanogr 46:573-583

Newell SY, Fallon RD (1991) Toward a method for measuring instantaneous fungal growth rates in field samples. Ecology 72:1547-1559

Newell SY, Moran MA, Wicks R, Hodson RE (1995) Productivities of microbial decomposers during early stages of decomposition of leaves of a freshwater sedge. Freshw Biol 34:135-148

Palumbo AV, Mulholland PJ, Elwood JW (1987) Microbial communities on leaf material protected from macroinvertebrate grazing in acidic and circumneutral streams. Can J Fish Aquat Sci 44:1064-1070

Robarts RD (1998) Incorporation of radioactive macromolecules as measures of bacterial growth: problems and pitfalls. In: Cooksey KE (ed) Molecular approaches to the study of the ocean. Chapman and Hall, London, p 471-486

Servais P (1990) Estimation de la production bactérienne en milieu marin par mesure du taux de synthèse protéique. Oceanol Acta 13:229-235

Sinsabaugh RL, Findlay SEG (1995) Microbial production, enzyme activity, and carbon turnover in surface sediments of the Hudson River estuary. Microb Ecol 30:127-141

Suberkropp K (1991) Relationships between growth and sporulation of aquatic hyphomycetes on decomposing leaf litter. Mycol Res 95:843-850

Suberkropp K (1992) Aquatic hyphomycete communities. In: Caroll GC, Wicklow DT (eds) The fungal community. Its organization and role in the ecosystem, 2nd edn. Dekker, New York, p 729-747

Suberkropp K (1995) The influence of nutrients on fungal growth, productivity, and sporulation during leaf breakdown in streams. Can J Bot 73(Suppl 1):1361-1369

Suberkropp K (1997) Annual production of leaf decaying

Editorial responsibility: Karelšimek,

České Budějovice, Czech Republic fungi in a woodland stream. Freshw Biol 38:169-178

Suberkropp K (1998a) Microorganisms and organic matter decomposition. In: Naiman RJ, Bilby RE (eds), River ecology and management: lessons from the Pacific Coastal Ecoregion. Springer-Verlag, Berlin, p 120-143

Suberkropp K (1998b) Effect of dissolved nutrients on two aquatic hyphomycetes growing on leaf litter. Mycol Res 102:998-1002

Suberkropp K (2001) Estimating production of litter-decomposing fungi in streams from rates of acetate incorporation into ergosterol. Verh Int Ver Limnol 27:2426-2429

Suberkropp K, Chauvet E (1995) Regulation of leaf breakdown by fungi in streams: influences of water chemistry. Ecology 76:1433-1445

Suberkropp K, Weyers HS (1996) Application of fungal and bacterial production methodologies to decomposing leaves in streams. Appl Environ Microbiol 62:1610-1615

Thomas O, Theraulaz F, Domeizel M, Massiani C (1993) UV spectral deconvolution: a valuable tool for wastewater quality determination. Environ Technol 14:1187-1192

Thomaz SM, Esteves FA (1997) Secondary productivity $\left({ }^{3} \mathrm{H}-\right.$ leucine and ${ }^{3} \mathrm{H}$-thymidine incorporation), abundance and biomass of the epiphytic bacteria attached to detritus of Typha domingensis Pers. in a tropical coastal lagoon. Hydrobiologia 357:17-26

Thomaz SM, Wetzel RG (1995) ${ }^{3} \mathrm{H}$-leucine incorporation methodology to estimate epiphytic bacterial biomass production. Microb Ecol 29:63-70

Thorp JH, Delong MD (1994) The riverine productivity model: an heuristic view of carbon sources and organic processing in large river ecosystems. Oikos 70:305-308

Tockner K, Pennetzdorfer D, Reiner N, Schiemer F, Ward JV (1999) Hydrological connectivity, and the exchange of organic matter and nutrients in a dynamic river-floodplain system (Danube, Austria). Freshw Biol 41:521-535

Voronin L (1992) Fungal complexes on dead macrophytes in Estonian lakes. Proc Estonian Acad Sci 41:77-85 (in Russian)

Ward JV, Tockner K, Arscott DB, Claret C (2002) Riverine landscape diversity. Freshw Biol 47:517-539

Webster J, Descals E (1981) Morphology, distribution, and ecology of conidial fungi in freshwater habitats. In: Cole GC, Kendrick B (eds) Biology of the conidial fungi, Vol 1. Academic Press, London, p 295-355

Weyers HS, Suberkropp K (1996) Fungal and bacterial production during the breakdown of yellow poplar leaves in two streams. J Nat Am Benthol Soc 15:408-420

Wieder RK, Lang GE (1982) A critique of the analytical methods used in examining decomposition data obtained from litter bags. Ecology 63:1636-1642

Wilkinson L (1990) SYSTAT: the system for statistics. Systat, Evanston, IL

Submitted: September 24, 2001; Accepted: February 19, 2002 Proofs received from author(s): April 17, 2002 